\title{
UNIVERSITYOF
}

FORWARD

THINKING

WESTMINSTER用

WestminsterResearch

http://www.westminster.ac.uk/westminsterresearch

Introduction: Effects and Affects of Conflict in the Heat of Battle and the Cold War of Words

Kelly, D.

This is an Accepted Manuscript of an article published by Taylor \& Francis in Journal of War and Culture Studies, 9 (1), 2016.

The final, definitive version is available online:

https://dx.doi.org/10.1080/17526272.2015.1115246.

The WestminsterResearch online digital archive at the University of Westminster aims to make the research output of the University available to a wider audience. Copyright and Moral Rights remain with the authors and/or copyright owners.

Whilst further distribution of specific materials from within this archive is forbidden, you may freely distribute the URL of WestminsterResearch: ((http://westminsterresearch.wmin.ac.uk/)).

In case of abuse or copyright appearing without permission e-mail repository@westminster.ac.uk 


\section{Varia 9.1 Introduction: Effects and Affects of Conflict in the Heat of Battle and the Cold War of Words}

Debra Kelly, University of Westminster

The centenary period of the First World War is approaching its mid-point as this varia issue is published at the beginning of 2016. 1916 was a turning point for military and public attitudes towards the war, and especially for European memory of it. 1916 was the year of Verdun and of the Somme, where hundreds of thousands of lives were lost for a few metres of ground in acts that came to be used as symbols for the incomprehension of subsequent generations, but did not prevent them engaging in further conflicts on huge and bloody scales.

It is fitting therefore that this issue begins with three articles which explore three aspects of the consequences of the First World War, and of its representation, in three different national contexts. Joanna Bourke's 'Love and Limblessness: Male Heterosexuality, Disability, and the Great War' takes as its focus the very real, but still often taboo, arena of love and sexuality in the aftermath of war in British culture. It analyses in a new light the subject of the 'Broken Heroes' who return home, with a focus on the 'effect' and 'affect' of this introduction's title both in the returning soldiers' own attitudes and behaviour, and in those of women towards men disabled by the war. Another experience of the physical and emotional impact of the war, this time in the Canadian cultural context, is explored in Irene Gammel's 'The Memory of St Julien: Configuring Gas Warfare in Mary Riter Hamilton's Battlefield Art'. The article not only explores the realities and representations of poison gas used for the first time as a weapon of warfare; it also brings to the fore the work of a female war artist, and a battlefield perspective long obscured by the Canadian war art establishment. In exploring the Second Battle of Ypres in 1915 and its representations of a key moment of Canadian nation-building, the article also provides a link to the third article in this Great War sequence. Karen Shelby's 'A Lion for Flanders: Literature, Propaganda and Flemish Nationalism' takes the example of how the memory of an iconic fourteenth-century battle, and the symbol of the Flemish Lion, is used within the political rhetoric of the Great War, in the creation of Flemish history and identity, and in public acts of commemoration and of national allegiance continuing to the present day. It further provides a link between the focus in the first two articles on the physical experiences of battle and that of the final two articles which deal, in very different contexts, with the ways in which language crafts the experience, memory and perceptions of war and of types of warfare, and with the ways it is used in what is broadly termed propaganda, although of very different types.

The chronological shifts of that article then also bring this varia issue to two later conflicts of the twentieth century. Firstly, the Second World War in Ester Lo Biundo's examination of the 'Voices of the Occupiers/Liberators: the BBC's Radio Propaganda in Italy between 1942 and 1945 '. While the role of the BBC and its various programming and war-time roles have been analysed in diverse ways, notably in the context of its broadcasting to France and its complex relations to different facets of the Resistance and of the Free French, this articles highlights the ambiguities of the role played by British propaganda and the use it made of Radio London in Italy. It further reveals tensions in the relationships between the BBC's Italian broadcasters, the anti-fascist cause, and the British authorities in the very particular situation of Italy's unconditional surrender. Finally, at a time when renewed tensions between Europe, America and Russia are making the headlines in theatres of war in the 
Middle East and beyond, and references to Cold War tactics abound in contemporary media, the concluding article takes us to another war of words, their effects and affects. Brian Balmer, Alex Spelling and Caitriona McCleish provide a timely reminder of the detail of the Cold War press in 'Preventing "A Virological Hiroshima": Cold War Press Coverage of Biological Weapons Disarmament' in the British and American newspaper media contexts. Also providing a link back to the earlier representation of the use of gas as a weapon in the Great War, this article examines debates around biological weapons in the comparatively recent history of the 1970 s and the Biological Weapons Convention. It explores the ambiguities of a discourse that condemns such weapons morally while balancing this condemnation against an assertion of their military effectiveness, and examines a second discourse which questions that effectiveness and their military value, adding a further layer of discursive complexity.

From the heat of battle to the cold war of words, a thread runs through this collection of articles concerned with both the effects and affects of war as their authors deal with physical maiming and its social consequences, the aftermath of historical gas attacks and the reactions engendered by the more recent threat of biological warfare, and the use of language in propaganda of all sorts as it is used to build cultural and national identity, to win 'hearts and minds', and to give contemporary shape to memories and commemorations of conflict. 